\title{
In Vitro Anti-inflammatory Activity of Fractionated Euphorbia hirta Aqueous Extract on Rabbit Synovial Fibroblasts
}

\author{
Jocelyn Chen ${ }^{1}$, Hui Meng Er ${ }^{2}$, Shar Mariam Mohamed ${ }^{1}$, Yu Sui Chen ${ }^{1}$
}

Background: Euphorbia hirta has been reported to possess anti-inflammatory activity. This study was carried out to determine the prostaglandin $\mathrm{E}_{2}\left(\mathrm{PGE}_{2}\right)$ inhibition activity of the fractions of the $E$. hirta aqueous extract on rabbit synovial fibroblast cells (HIG-82).

Methods: $\quad$ E. hirta aqueous extract was fractionated into five fractions (fractions A, B, C, D, and E) by reversed phase flash chromatography. Rabbit synovial fibroblast cells (HIG-82) were activated with phorbol myristate acetate and treated with the fractions. The amount of $\mathrm{PGE}_{2}$ released into the medium was measured by enzyme-linked immunosorbent assay.

Results: $\quad$ Fraction A $(0.1,1$, and $10 \mu \mathrm{g} / \mathrm{ml})$ had the greatest $\mathrm{PGE}_{2}$ inhibitory effect among the five fractions, and showed a greater extent of $\mathrm{PGE}_{2}$ inhibition compared to the aqueous extract. In contrast, Fraction E had the greatest stimulatory effect on $\mathrm{PGE}_{2}$ release.

Conclusions: Fraction $\mathrm{A}$ of the aqueous extract inhibited the production of $\mathrm{PGE}_{2}$ from activated HIG-82 cells to a greater extent than the crude aqueous extract. Bioactive compounds with anti-inflammatory activity are likely to be concentrated in Fraction A of E. hirta aqueous extract.

(Biomed J 2015;38:301-306)

\section{At a Glance Commentary}

Scientific background of the subject

Current drugs for the treatment of osteoarthritis are associated with safety, efficacy, and tolerability issues. Continuous effort to develop new drugs is necessary. Plants contain rich sources of bioactive compounds, from which new medicinal agents can be potentially isolated.

\section{What this study adds to the field}

The study showed that the fractionated aqueous extract of Euphorbia hirta was able to inhibit the production of prostaglandin $\mathrm{E}_{2}$ from activated rabbit synovial fibroblast cells. The findings are consistent with previous reports on the anti-inflammatory property of E. hirta. New antiarthritic agent can be potentially isolated from this plant.

Keywords: anti-inflammatory, Euphorbia hirta, fractionation, prostaglandin $\mathrm{E}_{2}$

$\mathrm{O}$ steoarthritis (OA) is the most common form of arthritis and affects up to $9.6 \%$ of men and $18 \%$ of women worldwide. ${ }^{[1]}$ It is the fourth leading cause of "years lost due to disability" (YLDs) at a global level and accounts for 3\% of total global YLDs. ${ }^{[2]}$ It is characterized pathologically by a general loss of articular cartilage, thickening of the subchondral bone, bony outgrowths (also known as osteophytes) at the joint margins, and mild but chronic synovial inflammation. ${ }^{[3]}$ It occurs most frequently as a phenomenon of aging and is thus irreversible. ${ }^{[4]}$

Synovial inflammation is increasingly being recognized as an important contributing factor in the pathogenesis of
OA. ${ }^{[5]}$ Synovial cells and chondrocytes have the capacity to produce a variety of cytokines and mediators associated with inflammation. Chondrocytes obtained from patients with OA actively produce nitric oxide, prostaglandins, interleukin (IL)-1 $\beta$, tumor necrosis factor $\alpha$, IL-6, and IL-8, which play a pivotal role in the disease process of OA. ${ }^{[6]}$ The expression of cyclooxygenase-2 (COX-2) has also been found to be elevated in the synovial tissues from patients with OA. ${ }^{[7]}$

Current advances in the development of antiarthritic agents have identified synovial inflammation as a potential therapeutic target. ${ }^{[6]}$ Nonsteroidal anti-inflammatory

From the ${ }^{1}$ School of Medicine, International Medical University, Kuala Lumpur, Malaysia; ${ }^{2}$ School of Pharmacy, International Medical University, Kuala Lumpur, Malaysia

Received: Jul. 18, 2014; Accepted: Jan. 13, 2015

Correspondence to: Dr. Hui Meng Er, School of Pharmacy, International Medical University, Kuala Lumpur, Malaysia. No. 126, Jalan Jalil Perkasa 19, Bukit Jalil, 57000 Kuala Lumpur, Malaysia. Tel: 603-86567228; Fax: 603-86567229; E-mail: huimeng_er@imu.edu.my

DOI: $10.4103 / 2319-4170.151031$ 
drugs (NSAIDs), which act by inhibiting the COX enzyme, are considered to be effective in the management of OA, but are associated with safety, efficacy, and tolerability issues. Thus, there is a need for the development of antiarthritic agents with better benefit-risk profiles.

Euphorbia hirta is a weed of the Euphorbiaceae or spurge family found commonly across the tropics. It is traditionally used for the treatment of gastrointestinal disease (diarrhea, dysentery, intestinal parasites), respiratory disease (asthma, bronchitis, and hay fever), treatment of skin ailments such as boils, and treatment of oral thrush. ${ }^{[8]}$ Its roots are used to increase lactation in breastfeeding mothers ${ }^{[8]}$ In vitro antibacterial activity against Escherichia coli, Staphylococcus aureus, Pseudomonas aeruginosa, and Bacillus subtilis has been reported, ${ }^{[9]}$ as well as antimalarial activity against Plasmodium falciparum. ${ }^{[10]}$ Anti-inflammatory and antidiarrheal activities have been demonstrated in induced mice models. ${ }^{[11,12]}$ In addition, studies by our research group have also shown that the aqueous extract of the plant possesses antioxidant, bronchodilatory, and antimutagenic activities. ${ }^{[13,14]}$ Besides, it exhibits the ability to inhibit production of matrix metalloproteinase (MMP)-13, a potent matrix degradative enzyme involved in OA that cleaves type II collagen ${ }^{[15]}$ Chemical constituents that have been reported in $E$. hirta include triterpenes, diterpene esters of the phorbol and ingenol types, sterols, tannins, ellagic acid, gallic acid, flavonoids including quercetin, quercitrin, rutin, and myricitrin, xanthorhamnin, hydrocarbon hentriacontane, and myricyl alcohol. ${ }^{[16,17]}$

This study aimed to evaluate the in vitro anti-inflammatory activity of the fractionated aqueous extract of $E$. hirta. The ability of the aqueous extract and its fractions to inhibit prostaglandin $(\mathrm{PG}) \mathrm{E}_{2}$ release in activated rabbit synovial fibroblasts was investigated.

\section{METHODS}

\section{Preparation of plant extract}

The plant material of E. hirta used in this study was authenticated by Roy Vickery, Department of Botany, The Natural History Museum, London.

In this preparation, the whole plant material was extracted in four solvents successively in an order of increasing polarity, namely $n$-hexane, chloroform, methanol, and water, using a Soxhlet extractor. This is a common method used in the initial screening and isolation of bioactive compounds from plants. Fatty material and chlorophyll are removed in the non-polar solvents ( $n$-hexane and chloroform). The same extraction method was used in the previously published studies by our research group. ${ }^{[13-15]}$ The yields of the extracts in the four solvents have been reported to be $2 \%, 1 \%, 7 \%$, and $16 \%$, respectively, from the dried plant material. ${ }^{[13]}$
As the aqueous extract was shown to possess the highest antioxidant activity among the extracts, ${ }^{[13]}$ all subsequent studies were carried out in the aqueous extract. A similar extraction method was also used by Prabhat et al. in the study of the anti-inflammatory activity of this plant against carrageenan-induced paw edema in rats. ${ }^{[18]}$

The whole plant material was washed and dried at $40^{\circ} \mathrm{C}$. The dried whole plant material $(30 \mathrm{~g})$ was powdered and extracted sequentially with $300 \mathrm{ml}$ each of $n$-hexane, chloroform, methanol, and water, using a Soxhlet extractor. The solvents in the extracts were removed under reduced pressure using a rotary evaporator. The water extract was further freeze-dried to obtain a consistent weight. The yield of the water extract was $12 \%$, based on the dry weight of the plant material.

\section{Determination of total phenolic content}

The total phenolic content of $E$. hirta aqueous extract was determined using Folin-Ciocalteu reagent using gallic acid as standard. ${ }^{[14]}$ The dried aqueous extract was reconstituted in water to a concentration of $0.5 \mathrm{mg} / \mathrm{ml}$. An aliquot of $20 \mu \mathrm{l}$ was mixed with $1.58 \mathrm{ml}$ of water in a cuvette. This was followed by addition of $100 \mu \mathrm{l}$ of Folin-Ciocalteu reagent. After mixing well and incubating for $5 \mathrm{~min}$, saturated sodium carbonate solution $(300 \mu \mathrm{l})$ was added and the mixture was incubated for $1 \mathrm{~h}$ at room temperature. The absorbance of the mixture was read at $760 \mathrm{~nm}$. Each sample was carried out in triplicates. The total phenolic content was determined from the gallic acid calibration curve and expressed as milligram of gallic acid equivalence (GAE) per gram of dried extract.

\section{Fractionation of plant extract by flash chromatography}

Carbon-18 reversed phase flash chromatography plastic disposable cartridges (SiliCycle Inc., Quebec, Canada; column volume $88 \mathrm{ml}$; column bed mass $10 \mathrm{~g}$; column diameter $20 \mathrm{~mm}$ ) were used for the fractionation of the aqueous extract. Prior to sample loading, the column was equilibrated with two column volumes of ultrapure water. The aqueous extract $(0.5 \mathrm{~g})$ was dissolved in $5 \mathrm{ml}$ of ultrapure water and loaded onto the sorbent bed, following which $25 \mathrm{ml}$ of ultrapure water was added. A vacuum pressure of $15 \mathrm{inHg}$ was applied and the flow rate was adjusted to $5-7 \mathrm{ml} / \mathrm{min}$. The eluent was collected into a $50 \mathrm{ml}$ conical flask. Subsequently, each of the following solvent mixtures was applied at a constant volume of $30 \mathrm{ml}$ twice and the eluents were collected separately: $100 \%$ water, $90 \%$ water $10 \%$ methanol, $80 \%$ water $/ 20 \%$ methanol, $60 \%$ water $/ 40 \%$ methanol, $40 \%$ water $/ 60 \%$ methanol, and $100 \%$ methanol. A total of 12 fractions were collected from each round of fractionation. 
The fractions were concentrated separately at $70^{\circ} \mathrm{C}$ using a rotary evaporator.

\section{Analysis of fractions by thin layer chromatography}

The collected fractions were analyzed by thin layer chromatography (TLC) using TLC Kieselgel $60 \mathrm{~F}_{254}$ silica gel plates (Merck, Darmstadt, Germany) of dimensions $20 \mathrm{~cm} \times 20 \mathrm{~cm}$. The concentrated fractions $(20 \mu \mathrm{l})$ were loaded onto a spot $2.5 \mathrm{~cm}$ above the edge of the TLC plate and evenly spaced out. The plate was dried at $60^{\circ} \mathrm{C}$ for 15 min before eluting with the TLC mobile phase in the chamber. The mobile phase used was $n$-butanol/glacial acetic acid/water (4:1:1). Fractions that showed similar TLC profiles under short-wavelength UV light $(254 \mathrm{~nm})$ were pooled together and dried to consistent weights using a freeze dryer (for fractions in water) or vacuum concentrator (for fractions containing methanol). Five final fractions were obtained and labeled as fractions A, B, C, D, and $\mathrm{E}$ (decreasing in polarity).

\section{Culturing of rabbit synovial fibroblast (HIG-82) cells}

The cell line used was rabbit synovial fibroblast cells (HIG-82). This was subcultured and maintained according to the general protocol from American Type Culture Collection (ATCC). The complete medium used for cell culture was Ham's F-12 medium supplemented with $10 \%$ fetal bovine serum (FBS) and 1\% penicillin-streptomycin solution. Cells were incubated at $37^{\circ} \mathrm{C}, 5 \% \mathrm{CO}_{2}$, and $70 \%$ humidity and split in a 1:4 ratio every $3-4$ days.

\section{Cytotoxicity assay}

The cytotoxic effects of the aqueous extract and fractions against HIG- 82 cells were assessed by measuring the viability of the cells treated with the aqueous extract or its fractions. This assay involved the reduction of yellow 3-(4,5-dimethylthiazol-2-yl)-2,5-diphenyltetrazolium bromide (MTT) to form purple formazan in the mitochondria of living cells. ${ }^{[19]}$ The aqueous extract or its fractions were dissolved in dimethyl sulfoxide (DMSO) to make up stock solutions of $50 \mathrm{mg} / \mathrm{ml}$. HIG- 82 cells $\left(1 \times 10^{4}\right.$ cells/well $)$ were plated in a $96-w e l l$ plate and incubated at $37^{\circ} \mathrm{C}$ for $24 \mathrm{~h}$. Following that, the cells were treated with the aqueous extract or its fractions $(1.56,3.13,6.25,12.5,25$, and $100 \mu \mathrm{g} / \mathrm{ml})$ and further incubated at $37^{\circ} \mathrm{C}$ for $72 \mathrm{~h}$. The concentration of DMSO in the wells was not more than $0.2 \%$ (v/v). Negative controls comprising cells in medium only were included in the assay. Then, $20 \mu \mathrm{l}$ of MTT solution $(5 \mathrm{mg} / \mathrm{ml}$ in phosphate-buffered saline) was added to each well, followed by further incubation at $37^{\circ} \mathrm{C}$ for $4 \mathrm{~h}$. DMSO $(100 \mu \mathrm{l})$ was added to each well to dissolve the formazan crystals and the absorbance in each well was determined at $570 \mathrm{~nm}$. The percentage cell viability was calculated using the formula:

Percentage cell viability $=($ absorbance of treated cells $/$ absorbance of negative control) $\times 100 \%$.

\section{PGE 2 assay}

The aqueous extract and Fraction A were prepared in complete medium to $1 \mathrm{mg} / \mathrm{ml}$, filtered through $0.22 \mu \mathrm{m}$ filter units, and further diluted to 100,10 , and $1 \mu \mathrm{g} / \mathrm{ml}$. Fractions B, C, D, and E were dissolved in DMSO to make up stock solutions of $10 \mathrm{mg} / \mathrm{ml}$. These were diluted with complete medium to $1 \mathrm{mg} / \mathrm{ml}$, filtered through $0.22 \mu \mathrm{m}$ filter units, and further diluted to 100,10 , and $1 \mu \mathrm{g} / \mathrm{ml}$. HIG-82 cells $\left(1.6 \times 10^{5}\right.$ cells/well $)$ were plated into each well of a sterile 24 -well plate. After $24 \mathrm{~h}$ of incubation, cells were activated with $0.1 \mu \mathrm{g} / \mathrm{ml}$ phorbol myristate acetate (PMA). This was immediately followed by treatment with the aqueous extract $(1 \mu \mathrm{g} / \mathrm{ml})$ or fraction $(0.1,1$, and $10 \mu \mathrm{g} / \mathrm{ml})$. Three controls were included in this assay. The first control was cells that were neither activated with PMA nor treated with the extract/fractions. The second control was cells that were activated with PMA but not treated with the extract/fractions. The third control was similar to the first control, but contained $0.1 \%$ DMSO in the medium. The final volumes in the wells were adjusted to $1 \mathrm{ml}$ with complete media. After $24 \mathrm{~h}$ of incubation, the medium was aspirated. $\mathrm{PGE}_{2}$ assay was carried out according to the instructions provided in the kit (Correlate-EIA High Sensitivity PGE ${ }_{2}$ Kit; Assay Designs, Ann Arbor, MI, USA). This assay is based on a competitive binding principle in which a monoclonal antibody to $\mathrm{PGE}_{2}$ binds to the $\mathrm{PGE}_{2}$ in the sample or an alkaline phosphatase molecule which has $\mathrm{PGE}_{2}$ covalently attached to it. After a simultaneous incubation at $4^{\circ} \mathrm{C}$ for $18-24 \mathrm{~h}$, the excess reagents were washed away and $p$-nitrophenyl phosphate (pNpp) substrate was added. The plate was then incubated at $37^{\circ} \mathrm{C}$ for $1 \mathrm{~h}$ to allow the reaction of pNpp with bound alkaline phosphatase to produce a yellow water-soluble product. After incubation, the enzyme reaction was stopped by addition of a stop solution. The absorbance in each well of the plate was read at $405 \mathrm{~nm}$ using a microplate reader. The intensity of the yellow color generated is inversely proportional to the concentration of $\mathrm{PGE}_{2}$ in either standards or samples.

\section{Statistical analysis}

All data are expressed as mean \pm standard deviation (SD). Data sets were assessed for normality by Kolmogorov-Smirnov test. Normally distributed data sets were analyzed by one-way analysis of variance (ANOVA) followed by Dunnett's post test. Data sets that were not of 
a normal distribution were analyzed by Kruskal-Wallis test. The differences between groups for cell viability in the MTT assay were analyzed by one-way ANOVA followed by Bonferroni post hoc analysis. All statistical analyses were performed using GraphPad Prism version 5.01 for Windows, GraphPad Software Inc., California, USA. Differences were considered significant at $p<0.05$.

\section{RESULTS AND DISCUSSION}

\section{Total phenolic content of $E$. hirta aqueous extract}

The total phenolic content of the aqueous extract was determined as GAE from the gallic acid standard curve [Figure 1]. The standard curve was obtained using the average absorbance values of two independent sets of data against gallic acid concentration. The phenolic content of the aqueous extract was $349 \mathrm{mg}$ GAE per gram of the aqueous extract. This is equivalent to $4082 \mathrm{mg}$ GAE per $100 \mathrm{~g}$ of dried plant (based on an $11.7 \%$ yield of the aqueous extract), which is more than five times that of green tea that has been reported to contain phenolic content of $770 \mathrm{mg}$ GAE per $100 \mathrm{~g}$ of dried herb. ${ }^{[20]}$ E. hirta aqueous extract has been reported to exhibit antioxidant activity comparable to that of commercial green and black teas. ${ }^{[13]}$ This suggests a potential role of the aqueous extract as a major dietary source of antioxidants.

\section{TLC profiling of fractions}

TLC separation of the 12 fractions obtained following fractionation of the aqueous extract showed five distinctive separation patterns under short-wavelength ultraviolet light [Figure 2]. Fractions showing the same separation patterns were pooled together in the following manner: Fractions 1 and 2, fractions 3 and 4, fractions 5 and 6 , fractions 7 and 8 , and fractions 9-12. The final five fractions obtained were labeled as fractions A, B, C, D, and E. The yields were $81 \%, 2.6 \%, 0.96 \%$, $0.65 \%$, and $0.53 \%$, respectively, based on the dry weight of the aqueous extract.

\section{Cytotoxicity assay}

The viabilities of HIG-82 cells treated with the aqueous extract or its fractions at various concentrations were calculated relative to untreated HIG- 82 cells. The results are shown in Figure 3 . The $\mathrm{IC}_{50}$ values of the aqueous extract and fractions $\mathrm{A}, \mathrm{B}$, and D exceeded $100 \mu \mathrm{g} / \mathrm{ml}$. The $\mathrm{IC}_{50}$ values of fractions $C$ and $E$ were approximately $90 \mu \mathrm{g} / \mathrm{ml}$.

The viability of the HIG-82 cells treated with $E$. hirta aqueous extract and Fraction A remained above $80 \%$ even at the highest concentration tested $(100 \mu \mathrm{g} / \mathrm{ml})$. These results

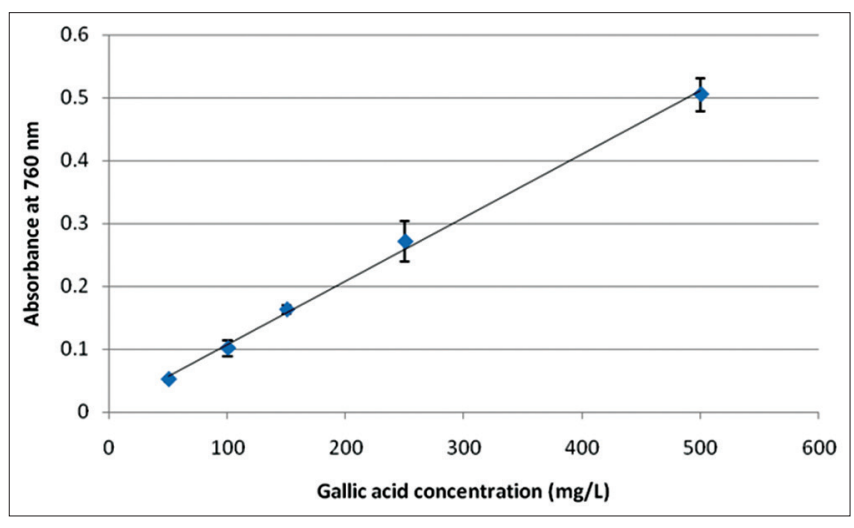

Figure 1: Standard curve of absorbance at $760 \mathrm{~nm}($ mean $\pm \mathrm{SD})$ versus gallic acid concentration $\left(y=0.001005 x+0.005266, r^{2}=0.9928\right)$.

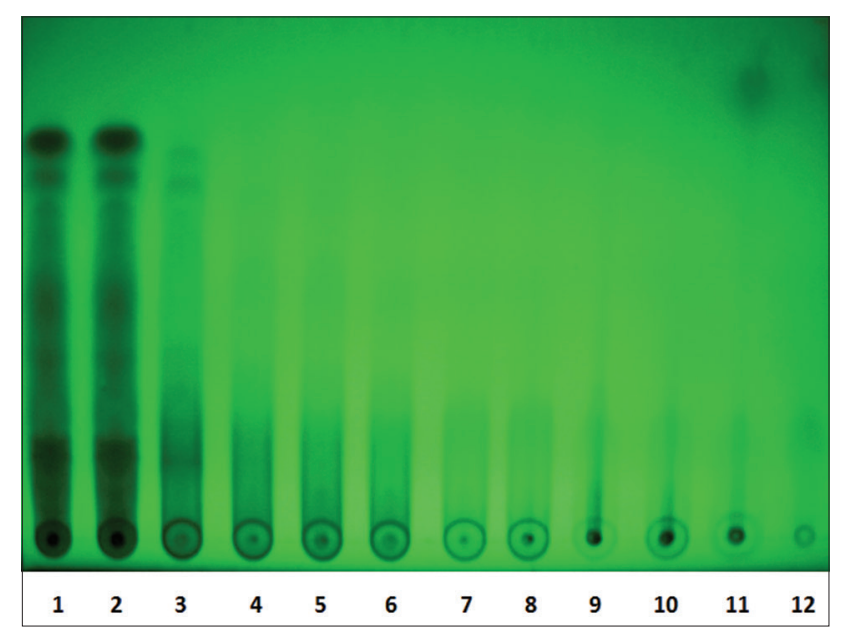

Figure 2: TLC separation patterns of 12 fractions showing five distinctive separation patterns under short-wavelength $(254 \mathrm{~nm})$ ultraviolet light.

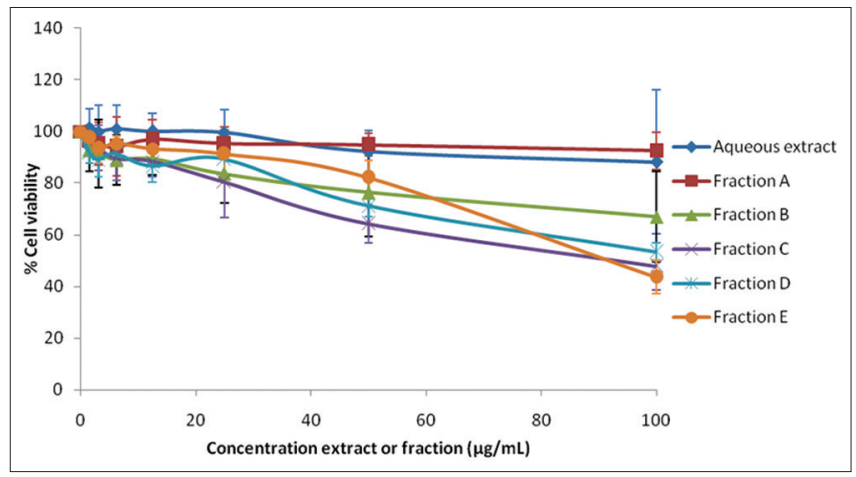

Figure 3: Dose-response curve showing the percentage of cell viability of HIG- 82 cells (mean $\pm \mathrm{SD}$ ) treated with the aqueous extract and fractions A-E of Euphorbia hirta $(n=6)$.

demonstrated that the aqueous extract and Fraction A were not cytotoxic against HIG-82 cells. However, fractionation of the aqueous extract resulted in an increase in the cytotoxicity of the other fractions, where the cell viability was reduced slightly upon treatment with Fraction B and markedly re- 
duced upon treatment with fractions C, D, and $\mathrm{E}(p<0.001)$. The results indicated that the cytotoxic bioactive compounds were mostly concentrated in fractions $\mathrm{C}, \mathrm{D}$, and $\mathrm{E}$.

\section{PGE $_{2}$ assay}

HIG-82 cells that were activated with PMA showed a 1.7-fold increase in $\mathrm{PGE}_{2 \text { sec }}$ retion compared to unactivated cells. Treatment with the aqueous extract decreased $\mathrm{PGE}_{2 \text { sec }}$ retion from $331 \mathrm{ng} / \mathrm{ml}$ to $317 \mathrm{ng} / \mathrm{ml}$. Fraction A reduced the production of $\mathrm{PGE}_{2}$ at all doses tested, with the largest inhibitory effect seen at $0.1 \mu \mathrm{g} / \mathrm{ml}\left(\mathrm{PGE}_{2}\right.$ concentration was $257 \mathrm{ng} / \mathrm{ml}$ ). Fraction $\mathrm{B}$ reduced the production of $\mathrm{PGE}_{2}$ at doses 1 and $10 \mu \mathrm{g} / \mathrm{ml}$, but increased the production of $\mathrm{PGE}_{2}$ at the dose of $0.1 \mu \mathrm{g} / \mathrm{ml}$. Fractions C, D, and E stimulated the production of $\mathrm{PGE}_{2}$ from HIG- 82 cells at all doses tested, with the greatest stimulatory effect by Fraction E at $1 \mu \mathrm{g} / \mathrm{ml}$. None of these changes were statistically significant relative to untreated PMA-activated cells. The results are presented in Figure 4. Previous studies by Hiermann and Bucar showed that the aqueous extract of the aerial parts of the plant strongly reduced $\mathrm{PGE}_{2}$ release from rat stomach at $100 \mu \mathrm{g} / \mathrm{ml} .^{[21]}$ Subsequent extraction of the crude aqueous extract with ethyl acetate showed that the ethyl acetate extract reduced the release of $\mathrm{PGE}_{2}$ to the same extent as the crude aqueous extract; however, the remaining aqueous phase after ethyl acetate extraction was ineffective. ${ }^{[21]}$ The proposed active principles of $E$. hirta could be compounds of medium polarity. ${ }^{[21]}$
The results of the $\mathrm{PGE}_{2}$ assay revealed that Fraction $\mathrm{A}$ at all concentrations tested and Fraction B ( 1 and $10 \mu \mathrm{g} / \mathrm{ml})$ inhibited $\mathrm{PGE}_{2}$ release from PMA-activated HIG-82 cells to a greater extent compared to that of the aqueous extract $(1 \mu \mathrm{g} / \mathrm{ml})$, though the differences were not statistically significant. These results showed that the bioactive compounds with $\mathrm{PGE}_{2}$ inhibitory effects were concentrated in fractions $\mathrm{A}$ and $\mathrm{B}$. On the other hand, fractions $\mathrm{C}, \mathrm{D}$, and $\mathrm{E}$ had a stimulatory effect on $\mathrm{PGE}_{2}$ production. It is interesting to note that while Fraction E exhibited the highest cytotoxic activity among the five fractions, Fraction $\mathrm{E}$ was also found to stimulate $\mathrm{PGE}_{2}$ production from PMA-activated HIG-82 cells to the greatest extent. The enhanced $\mathrm{PGE}_{2}$ production in Fraction E-treated PMA-activated HIG-82 cells could have induced apoptosis in the cells, as suggested by previous studies. ${ }^{[22]}$

PMA is one of the two recommended agents to activate production of $\mathrm{PGE}_{2}$ in HIG-82 cells. ${ }^{[23]}$ In another study, inhibition of $\mathrm{PGE}_{2}$ release was also found when bradykinin-activated $3 \mathrm{~T} 3$ cells were treated with the E. hirta aqueous extract (unpublished data). Although phorbol esters have been reported in E. hirta ${ }^{[16]}$ as the plant material was sequentially extracted in $n$-hexane, chloroform, methanol, and water following this order, the phorbol ester compounds, being soluble in polar organic solvents, ${ }^{[24]}$ would likely to have been extracted into the methanol fraction. Therefore, it is unlikely that they would cause interference in the $\mathrm{PGE}_{2}$ assay carried out in the aqueous extract.

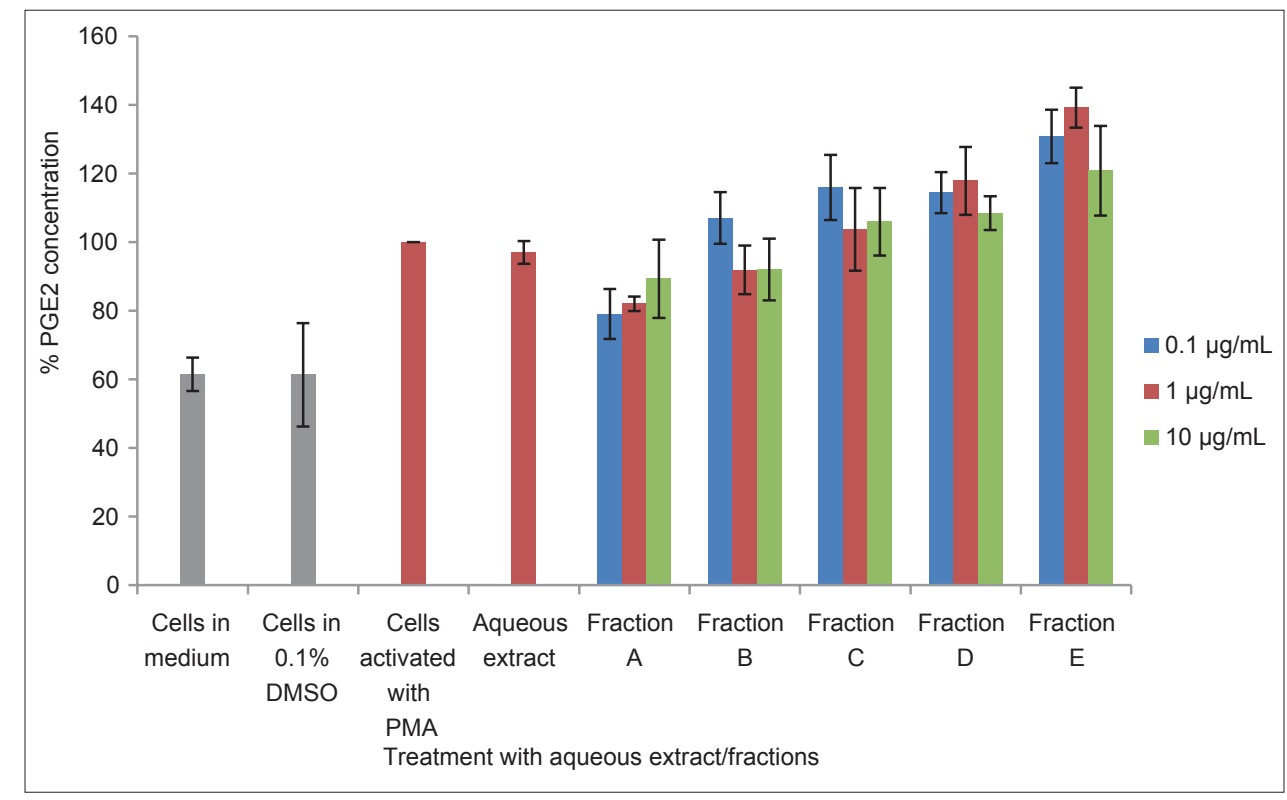

Figure 4: Bar charts showing percentage of $\mathrm{PGE}_{2}$ release (mean $\pm \mathrm{SEM}$ ) of the negative controls/treatment groups relative to the PMAactivated but untreated HIG-82 cells: unactivated HIG-82 cells in medium $(n=6)$; unactivated HIG-82 cells in medium containing $0.1 \%$ DMSO $(n=2)$; PMA-activated HIG-82 cells $(n=6)$; PMA-activated HIG-82 cells treated with the aqueous extract $(1 \mu \mathrm{g} / \mathrm{ml})$ or fractions A-E $(0.1,1$, and $10 \mu \mathrm{g} / \mathrm{ml})(n=6)$. None of the treatment groups (aqueous extract/fractions) showed statistically significant difference from the cells activated with PMA. 
The mechanism by which Fraction A exerts its anti-inflammatory effect should be further explored. $\mathrm{PGE}_{2}$ synthesis depends on the availability of arachidonic acid as well as activation of COX. Therefore, it is reasonable to examine the effect of Fraction A on COX activity, especially COX-2 and phospholipase $\mathrm{A}_{2}$ activities. Meanwhile, the effect of the plant on the lipoxygenase (LOX) pathway should also be investigated for two reasons. Firstly, cellular $\mathrm{PGE}_{2}$ levels may modulate the expression of enzymes in the LOX pathway via a shunt from the COX to the LOX pathway. ${ }^{[25]}$ Secondly, metabolites of this pathway, especially leukotriene $\mathrm{B}_{4}$, are proinflammatory and have been shown to contribute to the pathophysiology of arthritis. ${ }^{[26]}$

\section{Conclusions}

Fraction A of the E. hirta aqueous extract showed a more promising anti-inflammatory activity via inhibitory effect on $\mathrm{PGE}_{2}$ production compared to the crude aqueous extract. This fraction was also found to be non-cytotoxic against HIG-82 cells. The bioactive compounds in Fraction A that are responsible for its anti-inflammatory activity should be further identified and characterized.

\section{Acknowledgment}

This research work was supported by the International Medical University Grant.

\section{REFERENCES}

1. Woolf AD, Pfleger B. Burden of major musculoskeletal conditions. Bull World Health Organ 2003;81:646-56.

2. Symmons D, Mathers C, Pfleger B. Global burden of osteoarthritis in the year 2000. Geneva: World Health Organization; 2006.

3. Berenbaum F. Osteoarthritis: Pathology and pathogenesis. In Primer on the Rheumatic Diseases. $13^{\text {th }}$ ed. In: Klippel JH, Stone JH, Crofford LJ, White PH, editors. New York: Springer; 2008. p. 229-34.

4. Rosenberg AE. Bones, joints and soft tissue tumors. In Robbins and Cotran Pathologic Basis of Disease. $7^{\text {th }}$ ed. In: Kumar V, Abbas AK, Fausto N, editors. Philadelphia: Elsevier; 2005. p. 1304-5.

5. Bonnet CS, Walsh DA. Osteoarthritis, angiogenesis and inflammation. Rheumatology 2005;44:7-16.

6. Pelletier JP, Martel-Pelletier J, Abramson SB. Osteoarthritis, an inflammatory disease: Potential implication for the selection of new therapeutic targets. Arthritis Rheum 2001;44:1237-47.

7. Siegle I, Klein T, Backman JT, Saal JG, Nusing RM, Fritz P. Expression of cyclooxygenase 1 and cyclooxygenase 2 in human synovial tissue: Differential elevation of cyclooxygenase 2 in inflammatory joint diseases. Arthritis Rheum 1998;41:122-9.

8. Kumar S, Malhotra R, Kumar D. Euphorbia hirta: Its chemistry, traditional and medicinal uses, and pharmacological activities. Pharmacogn Rev 2010;4:58-61.

9. Ogbulie JN, Ogueke CC, Okoli IC, Anyanwu BN. Antibacterial activities and toxicological potentials of crude ethanolic extracts of Euphorbia hirta. Afr J Biotechnol 2007;6:1544-8.

10. Liu Y, Murakami N, Ji H, Abreu P, Zhang S. Antimalarial flavonol glycosides from Euphorbia hirta. Pharm Biol 2007;45:278-81.

11. Lanhers MC, Fleurentin J, Dorfman P, Mortier F, Pelt JM. Analgesic, antipyretic and anti-inflammatory properties of Euphorbia hirta. Planta Med 1991;57:225-31.

12. Galvez J, Zarzuelo A, Crespo ME, Lorente MD, Ocete MA, Jimenez J Antidiarrhoeic activity of Euphorbia hirta extract and isolation of an active flavonoid constituent. Planta Med 1993;59:333-6.

13. Chen YS, Er HM. Antioxidant, anti-proliferative and bronchodilatory activities of Euphorbia hirta extracts. Malays J Sci 2010;29:22-9.

14. Loh DS, Er HM, Chen YS. Mutagenic and antimutagenic activities of aqueous and methanol extracts of Euphorbia hirta. J Ethnopharmacol 2009;126:406-14.

15. Lee KH, Chen YS, Judson JP, Chakravarthi S, Sim YM, Er HM. The effect of water extracts of Euphorbia hirta on cartilage degeneration in arthritic rats. Malaysian J Pathol 2008;30:95-102.

16. Tabuti JRS. Euphorbia hirta L. In: Schmelzer GH, Gurib-Fakim A, editors. Prota 11 (1): Medicinal plants/Plantes médicinales 1. [CD-Rom]. Wageningen, Netherlands: PROTA; 2008.

17. Gupta DR, Garf SK. A chemical examination of Euphobia hirta Linn. Bull Chem Soc Jpn 1966;39:2532-4.

18. Prabhat D, Suman M, Saumya P, Ranhan S, Praveen N. Pharmacological evaluation of anti-inflammatory activity of Euphorbia hirta against carrageenan induced paw edema in rats. Der Pharm Lett 2010;2:1511-5.

19. Mosmann T. Rapid colorimetric assay for cellular growth and survival: Application to proliferation and cytotoxicity assays. J Immunol Methods 1983;65:55-63.

20. Yoo KM, Lee CH, Lee H, Moon B, Lee CY. Relative antioxidant and cytoprotective activities of common herbs. Food Chem 2008;106:929-36.

21. Hiermann A, Bucar F. Influence of some traditional medicinal plants of Senegal on prostaglandin biosynthesis. J Ethnopharmacol 1994;42:111-6.

22. Huang SK, White ES, Wettlaufer SH, Grifka H, Hogaboam CM, Thannickal VJ, et al. Prostaglandin $\mathrm{E}_{2}$ induces fibroblast apoptosis by modulating multiple survival pathways. FASEB J 2009;23:4317-26.

23. ATCC Cell Biology Collection. Available from: http://www.atcc.org/ en/Products/Cells and Microorganisms/Cell Lines/Animal/Rabbit/ CRL-1832.aspx\#characteristics] [Last accessed on 2014 Nov 06].

24. Devappa RK, Makkar HP, Becker K. Optimization of conditions for the extraction of phorbol esters from Jatropha oil. Biomass Bioenergy 2010;34:1125-33.

25. Maxis K, Delalandre A, Martel-Pelletier J, Pelletier JP, Duval N, Lajeunesse D. The shunt from the cyclooxygenase to lipoxygenase pathway in human osteoarthritic subchondral osteoblasts is linked with a variable expression of the 5-lipoxygenase-activating protein. Arthritis Res Ther 2006;8:R181.

26. Martel-Pelletier J, Mineau F, Fahmi H, Laufer S, Reboul P, Boileau C, et al. Regulation of the expression of 5-lipoxygenase-activating protein/5-lipoxygenase and the synthesis of leukotriene $B_{4}$ in osteoarthritic chondrocytes: Role of transforming growth factor beta and eicosanoids. Arthritis Rheum 2004;50:3925-33. 